\title{
Methylene blue administration in the compound 48/80-induced anaphylactic shock. Hemodynamic study in pigs ${ }^{1}$
}

\author{
Administração de azul de metileno no choque anafilático induzido por composto 48/80. \\ Estudo hemodinâmico em suínos.
}

\begin{abstract}
Antonio Carlos Menardi', Verena Kise Capellini" ${ }^{\mathrm{II}}$, Andrea Carla Celotto ${ }^{\mathrm{III}}$, Agnes Afrodite Sumarelli Albuquerque ${ }^{\mathrm{IV}}$, Fernanda Viarov, Walter Vilella A. Vicente $^{\mathrm{VI}}$, Alfredo José Rodrigues ${ }^{\mathrm{VII}}$, Paulo Roberto Barbosa Evora ${ }^{\mathrm{VIII}}$

${ }^{I}$ Assistant Professor, Department of Surgery and Anatomy, FMRP-USP, Ribeirao Preto-SPo, Brazil. Responsible for intellectual and scientific content of the study, acquisition and interpretation of data, designed the protocol, involved with technical procedures, provided guidelines for the surgical interventions.

IFellow PhD degree, Laboratory of Endothelial Function, Department of Surgery and Anatomy, FMRP-USP, Ribeirao Preto-SP, Brazil. Responsible for manuscript writing, responsible for English language, critical revision.

IIIBsC, PhD, Laboratory of Endothelial Function, Department of Surgery and Anatomy, FMRP-USP, Ribeirao Preto-SP, Brazil. Responsible for manuscript writing, responsible for English language, critical revision.

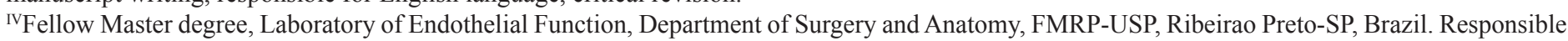
for manuscript writing, critical revision.

${ }^{\mathrm{B}} \mathrm{BsC}, \mathrm{MD}$, Laboratory of Endothelial Function, Department of Surgery and Anatomy, FMRP-USP, Ribeirao Preto-SP, Brazil. Acquisition and interpretation of data, provided guidelines for the surgical interventions, statistical analysis.

${ }^{\mathrm{V}} \mathrm{PhD}$, Associate Professor, Head of Division of Thorax and Cardiovascular Surgery, Department of Surgery and Anatomy, FMRP-USP, Ribeirao Preto-SP, Brazil. Designed the protocol, involved with technical procedures, provided guidelines for the surgical interventions, helped with technical procedures, analysis and interpretation of data.

${ }^{\mathrm{VII}} \mathrm{PhD}$, Assistant Professor, Division of Thorax and Cardiovascular Surgery, Department of Surgery and Anatomy of Faculty of Medicine of Ribeirao Preto of University of Sao Paulo (FMRP-USP), Ribeirao Preto, Sao Paulo, Brazil. Helped with technical procedures, collection and processing of study informations.

VIIIPhD, Full Professor, Division of Thorax and Cardiovascular Surgery, Department of Surgery and Anatomy, FMRP-USP, Ribeirao Preto-SP, Brazil. Responsible for intellectual and scientific content of the study, responsible for manuscript writing, designed the protocol, involved with technical procedures, provided guidelines for the surgical interventions, critical revision.
\end{abstract}

\section{ABSTRACT}

PURPOSE: To verify if the methylene blue (MB) administration prevents and/or reverses the compound 48/80 (C48/80)-induced anaphylactic shock in pigs.

METHODS: Female Dalland pigs were anesthetized and had the hemodynamic parameters recorded during the necessary time to administer some drugs and observe their effect. The animals were randomly assigned to one of the five groups: 1) control; 2) MB: the animals received a bolus injection of MB $(2 \mathrm{mg} / \mathrm{kg})$ followed by continuous infusion of $\mathrm{MB}(2.66 \mathrm{mg} / \mathrm{Kg} / \mathrm{h}$ delivered by syringe infusion pump); 3) C48/80: the animals received a bolus injection of $\mathrm{C} 48 / 80(4 \mathrm{mg} / \mathrm{kg})$; 4) C48/80+MB: the animals received a bolus injection of C48/80 (4 mg/kg) and 10 minutes after the C48/80 administration the animals received a bolus injection of MB $(2 \mathrm{mg} / \mathrm{kg})$ followed by continuous infusion of $\mathrm{MB}(2.66 \mathrm{mg} / \mathrm{Kg} / \mathrm{h}$ delivered by syringe infusion pump); 5) $\mathrm{MB}+\mathrm{C} 48 / 80$ : the animals received a bolus injection of MB (2 mg/kg) and 3 minutes later they received a bolus injection of C48/80 (4 mg/kg).

RESULTS: The intravenous infusion of MB alone caused no changes in the mean arterial pressure (MAP) showing that the administered MB dose was safe in this experimental model. The $\mathrm{C} 48 / 80$ was effective in producing experimental anaphylactic shock since it was observed a decrease in both MAP and cardiac output (CO) after its administration. The MB did not prevent or reverse the C48/80induced anaphylactic shock in this model. In fact, the MAP of the animals with anaphylactic shock treated with MB decreased even more than the MAP of the animals from the $\mathrm{C} 48 / 80$ group. On the other hand, the $\mathrm{C} 48 / 80$-induced epidermal alterations disappeared after the MB infusion.

CONCLUSION: Despite our data, the clinical manifestations improvement brings some optimism and does not allow excluding the $\mathrm{MB}$ as a possible therapeutic option in the anaphylactic shock.

Keywords: Nitric Oxide. Methylene Blue. Anaphylaxis. Guanylate Cyclase. Swine. 


\section{RESUMO}

OBJETIVO: Verificar se a administração de azul de metileno (AM) previne e/ou reverte o choque anafilático induzido por composto 48/80 (C48/80) em suínos.

MÉTODOS: Porcos fêmeas Dalland foram anestesiados e tiveram os parâmetros hemodinâmicos registados durante o tempo necessário para administrar algumas drogas e observar seu efeito. Os animais foram aleatoriamente destribuídos em um dos cinco grupos: 1) controle, 2) AM: os animais receberam uma injeção em bolus de AM (2mg/kg), seguido de infusão contínua de AM (2,66mg/Kg /h por bomba de infusão de seringa); 3) C48/80: os animais receberam uma injeção em bolus de C48/80 (4mg/kg); 4) C48/80 + AM: os animais receberam uma injeção em bolus de C48/80 (4mg/kg) e 10 minutos após a administração de C48/80 os animais receberam uma injeção em bolus de AM (2mg/kg), seguido de infusão contínua de AM (2,66mg/kg/h por bomba de infusão de seringa); 5) AM+C48/80: os animais receberam uma injeção em bolus de AM (2mg/kg) e três minutos depois, receberam uma injeção em bolus de C48/80 (4mg/kg). RESULTADOS: A infusão intravenosa de AM não causou mudanças na pressão arterial média (PAM), mostrando que a dose de AM administrada foi segura neste modelo experimental. O C48/80 foi eficaz na indução do choque anafilático experimental, uma vez que foi observada redução na PAM e débito cardíaco (DC), após a sua administração. O AM não preveniu ou reverte o choque anafilático induzido por C48/80 neste modelo. Na verdade, a PAM dos animais com choque anafilático tratados com AM diminuiu mais do que o PAM dos animais do grupo C48/80. Por outro lado, as alterações epidérmicas induzidas pelo C48/80 desapareceu após a infusão do AM. CONCLUSÃO: Apesar dos resultados a melhora clínica das manifestações anafiláticas permite considerar a possibilidade do azul de metileno como opção terapêutica no tratamento do choque anafilático.

Descritores: Óxido Nítrico. Azul de Metileno. Anafilaxia. Guanilato Ciclase. Suínos.

\section{Introduction}

It is currently known that nitric oxide (NO) is associated with vasoplegic reactions in sepsis ${ }^{1-11}$, anaphylaxis ${ }^{12-17}$ and cardiopulmonary bypass related systemic inflammatory response syndrome (SIRS). NO is a powerful endogenous vasodilatator. The nitric oxide synthases (NOS) are the enzymes responsible for converting L-arginine in NO and L-citrulline. Experimental studies in rabbits demonstrated that the NOS inhibition by L-arginine analogs reverses anaphylactic hypotension ${ }^{18}$. But, these inhibitors cause cardiac output decrease and pulmonary vascular resistance increase ${ }^{13,14,19}$. Also, it is important to emphasize that L-arginine analogs inhibit both endothelial (eNOS) and inducible (iNOS) NOS isoforms. The ideal would be inhibit specifically the iNOS, which is responsible for vasoplegic reactions, preserving the eNOS activity, which has a vital role for the microcirculation physiology $y^{1,13}$. The NO synthesis inhibition is still a matter of controversy and, even a matter of bioethics. So, the blockade of the NO effects on the vascular smooth muscle, via guanylyl cyclase (GC) inhibition, would be a reasonable strategy ${ }^{20}$. The GC increases the cyclic guanosine 3',5'-monophosphate (cGMP) levels promoting vasodilation. In some studies, the methylene blue (MB), a GC inhibitor, reversed the anaphylactic shock ${ }^{16,17,21}$. Since these studies involved a small number of patients, the
MB effectiveness and safety have been questioned. Therefore, the present study aimed to verify if the $\mathrm{MB}$ administration prevents and/or reverses the compound 48/80 (C48/80)-induced anaphylactic shock in pigs.

\section{Methods}

\section{Animal preparation and hemodynamic parameters}

Female Dalland pigs $(22-26 \mathrm{~kg})$ were induced to anesthesia with intramuscular administration of midazolan (15 $\mathrm{mg} / \mathrm{kg}$, Dormid ${ }^{\circledR}$, Cristália Produtos Químicos Ltda., SP, Brazil) and tiletamine/zolazepam $\left(10 \mathrm{mg} / \mathrm{kg}\right.$, Telazol ${ }^{\circledR}$, Fort Dodge, IA, EUA). Maintenance was achieved by total intravenous anesthesia using sulfentanyl $\left(100 \mu \mathrm{g} / \mathrm{h}\right.$, Fastfan $^{\circledR}$, Cristália Produtos Químicos Ltda., SP, Brazil) and propofol $\left(10 \mathrm{mg} / \mathrm{Kg} / \mathrm{h}\right.$, Propovan ${ }^{\circledR}$, Cristália Produtos Químicos Ltda., SP, Brazil) delivered by syringe infusion pump (Syringe Infusion Pump, Harvard Apparatus, MA, EUA). Pancuronium bromide (6 mg/h, Pancuron ${ }^{\circledR}$, Cristália Produtos Químicos Ltda., SP, Brazil) was used as a muscular relaxant. Tracheostomy was performed on all animals immediately after induction of anesthesia. Volemia maintenance was achieved with intravenous infusion of sodium chloride $0.9 \%$ (5 mL/kg/h). A Swan-Ganz CCOmbo CCO/SvO2 744HF75 (Edwards Lifesciences, CA, EUA) catheter was placed in the right 
jugular vein and into the lumen of the main pulmonary artery. The left carotid was simultaneously catheterized. Mean arterial pressure (MAP), pulmonary arterial pressure (PAP), pulmonary capillary pressure (PCP) and central venous pressure (CVP) were recorded by the MP System 100 A (BioPac System, Inc., CA, EUA). Cardiac output (CO), systemic vascular resistance (SVR) and pulmonary vascular resistance (PVR) were obtained by the Vigilance System (Edwards Lifesciences LLC, CA, EUA). After instrumentation, a period of 20 minutes was allowed for anesthesia stabilization. After that, the hemodynamic parameters and the clinical condition were recorded for 15 minutes.

\section{Experimental design}

The animals $(n=30)$ were randomly assigned to one of the five groups:

1. control: the animals received the same volume of the vehicle used to prepare the drugs in the other groups at the same time points;

2. MB: immediately after the 20 minutes stabilization the animals received a bolus injection of $\mathrm{MB}(2 \mathrm{mg} / \mathrm{kg})$ followed by continuous infusion of MB $(2.66 \mathrm{mg} / \mathrm{Kg} / \mathrm{h}$ delivered by syringe infusion pump);

3. C48/80: immediately after the 20 minutes stabilization the animals received a bolus injection of $\mathrm{C} 48 / 80(4 \mathrm{mg} / \mathrm{kg})$;

4. C48/80+MB: immediately after the 20 minutes stabilization the animals received a bolus injection of $\mathrm{C} 48 / 80$ (4 $\mathrm{mg} / \mathrm{kg}$ ) and 10 minutes after the $\mathrm{C} 48 / 80$ administration the animals received a bolus injection of $\mathrm{MB}(2 \mathrm{mg} / \mathrm{kg})$ followed by continuous infusion of $\mathrm{MB}(2.66 \mathrm{mg} / \mathrm{Kg} / \mathrm{h}$ delivered by syringe infusion pump);

5. $\mathrm{MB}+\mathrm{C} 48 / 80$ : immediately after the 20 minutes stabilization the animals received a bolus injection of MB (2 mg/ $\mathrm{kg}$ ) and 3 minutes later they received a bolus injection of $\mathrm{C} 48 / 80$ (4 mg/kg).

\section{Statistical analysis}

The results are expressed as mean \pm standard error of the mean (SEM) and were analyzed using analysis of variance (oneway ANOVA) and Bonferroni post-test (Prism 4.0, GraphPad Software Inc., San Diego, CA, USA). Values were considered to be statistically significant at $\mathrm{p}$ values smaller than 0.05 .

\section{Results}

\section{Clinical observations}

There were no clinical alterations after MB injection in the MB group.

Five from six animals in the C48/80 group presented cutaneous hyperemia, vomits and sphincters liberation approximately 2 minutes after the injection of this compound. Livedo reticularis and cyanosis appeared a little bit later, persisting until the end of the experiment, when ascites and intestinal ischemia and distention were also observed.

Four from six animals in the $\mathrm{C} 48 / 80+\mathrm{MB}$ group presented cutaneous hyperemia, vomits and sphincters liberation about two minutes after the $\mathrm{C} 48 / 80$ administration, but after the $\mathrm{MB}$ infusion the epidermal alterations disappeared, and there was an apparent better peripheral perfusion.

None of the six animals in the $\mathrm{MB}+\mathrm{C} 48 / 80$ group presented clinical changes after the MB injection, but all of them presented cutaneous hyperemia (which decreased slow in two animals) and five of them presented vomits and sphincters liberation after $\mathrm{C} 48 / 80$ administration.

\section{Hemodynamic observations}

Mean arterial pressure (MAP)

Only one animal in the MB group had, immediately after MB injection, an increase in MAP which was spontaneously normalized in about 10 minutes. However, there were no changes in MAP between the control and the MB groups, showing that the administered MB dose was safe in this experimental model (Figure 1A).

The C48/80 group presented a hypotension which was statistically significant from $5^{\text {th }}$ to $14^{\text {th }}$ minute in the comparison with the control group (Figure 1A). 


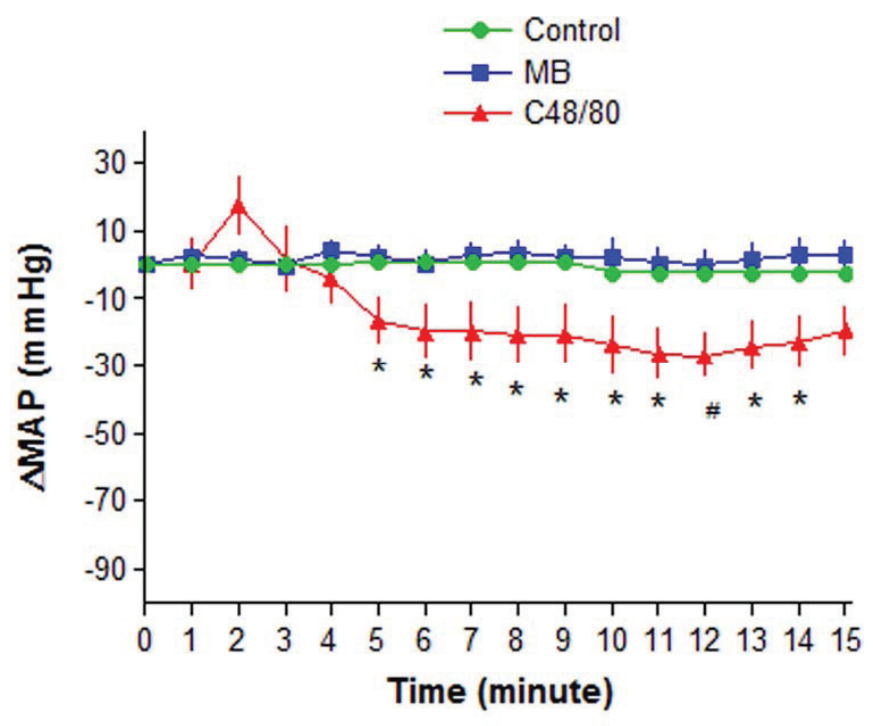

FIGURE 1A - Mean arterial pressure (MAP) in the control, methylene blue (MB) and compound 48/80 (C48/80) groups. All values are means \pm SEM ( $n=6$ in each group) and represent the MAP variation ( $\triangle \mathrm{MAP}$ $\left.=\mathrm{MAP}_{\mathrm{t}}-\mathrm{MAP}_{\mathrm{t}=0}\right)$ in each time point ( $\mathrm{t}$ varies from 0 to 15 minutes). * $\mathrm{p}<0.05,{ }^{\#} \mathrm{p}<0.01$ in the comparison between control and C48/80 (Oneway ANOVA, Bonferroni's Multiple Comparison Test).

The C48/80+MB group presented a larger decrease in the MAP than the C48/80 group with statistical difference between the $6^{\text {th }}$ and the $9^{\text {th }}$ minute (Figure $1 \mathrm{~B}$ ).

There were no differences between the $\mathrm{C} 48 / 80$ and $\mathrm{MB}+\mathrm{C} 48 / 80$ (Figure 1B).

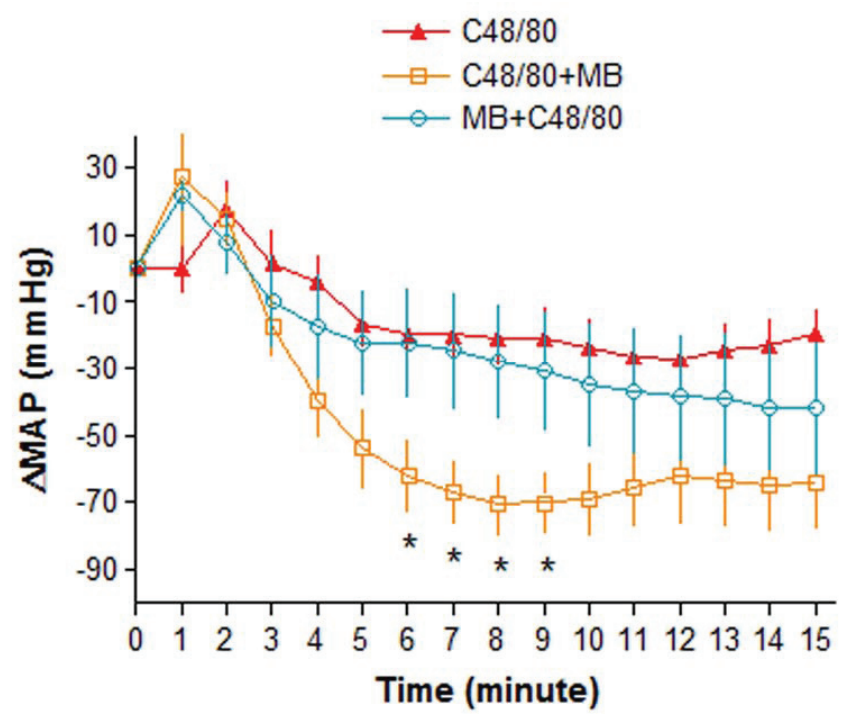

FIGURE 1B - Mean arterial pressure (MAP) in the compound 48/80 (C48/80), C48/80 followed by methylene blue $(\mathrm{C} 48 / 80+\mathrm{MB})$ and methylene blue followed by $\mathrm{C} 48 / 80(\mathrm{MB}+\mathrm{C} 48 / 80)$ groups. All values are means \pm SEM ( $\mathrm{n}=6$ in each group) and represent the MAP variation $\left(\triangle \mathrm{MAP}=\mathrm{MAP}_{\mathrm{t}}-\mathrm{MAP}_{\mathrm{t}=0}\right)$ in each time point ( $\mathrm{t}$ varies from 0 to 15 minutes). ${ }^{*} \mathrm{p}<0.05$ in the comparison between control and $\mathrm{C} 48 / 80$ (Oneway ANOVA, Bonferroni's Multiple Comparison Test).

\section{Pulmonary arterial pressure (PAP)}

The control group presented a stable PAP (Figure 2A).

In the MB group, the PAP decreased a little from $5^{\text {th }}$ to $7^{\text {th }}$ minute, but it was completely recovered in the $12^{\text {nd }}$ minute. However, these differences did not reach statistical significance in comparison to the control group (Figure 2A).

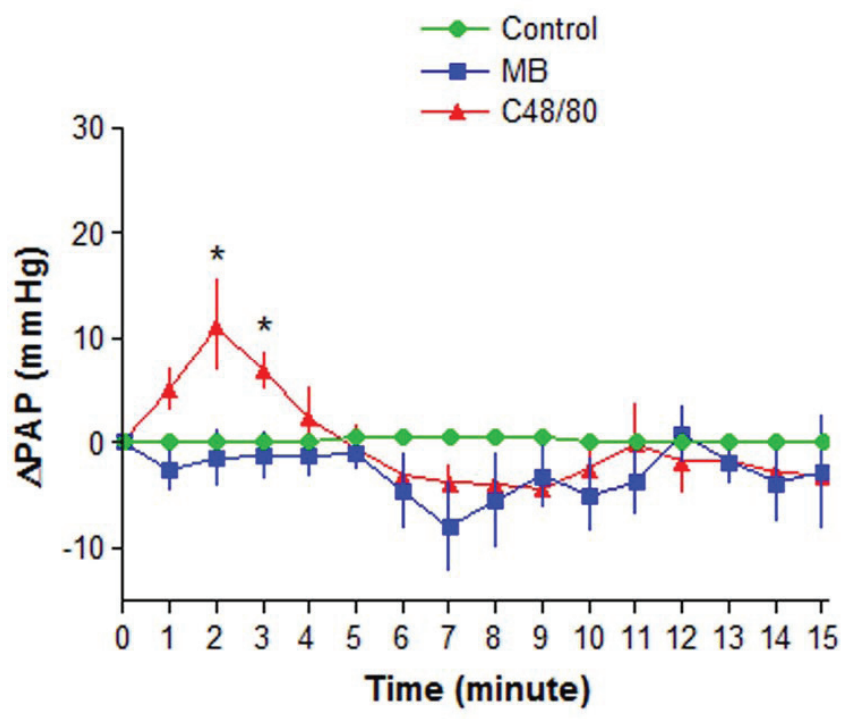

FIGURE 2A - Pulmonary arterial pressure (PAP) in the control, methylene blue (MB) and compound 48/80 (C48/80) groups. All values are means $\pm \mathrm{SEM}$ ( $\mathrm{n}=6$ in each group) and represent the PAP variation $(\triangle \mathrm{PAP}=$ $\left.\mathrm{PAP}_{\mathrm{t}}-\mathrm{PAP}_{\mathrm{t}=0}\right)$ in each time point ( $\mathrm{t}$ varies from 0 to 15 minutes). ${ }^{*} \mathrm{p}<0.05$ in the comparison between control and C48/80 (One-way ANOVA, Bonferroni's Multiple Comparison Test).

The $C 48 / 80$ group presented a lung hypertension in the beginning of the experiment (statistically significant in the $2^{\text {nd }}$ and $3^{\text {rd }}$ minutes compared to the control group) returning to the basal levels in the $4^{\text {th }}$ minute (Figure $2 \mathrm{~B}$ ).

There were no statistical differences between the $\mathrm{C} 48 / 80$ and the $\mathrm{C} 48 / 80+\mathrm{MB}$ or $\mathrm{MB}+\mathrm{C} 48 / 80$ (Figure $2 \mathrm{~B}$ ). 


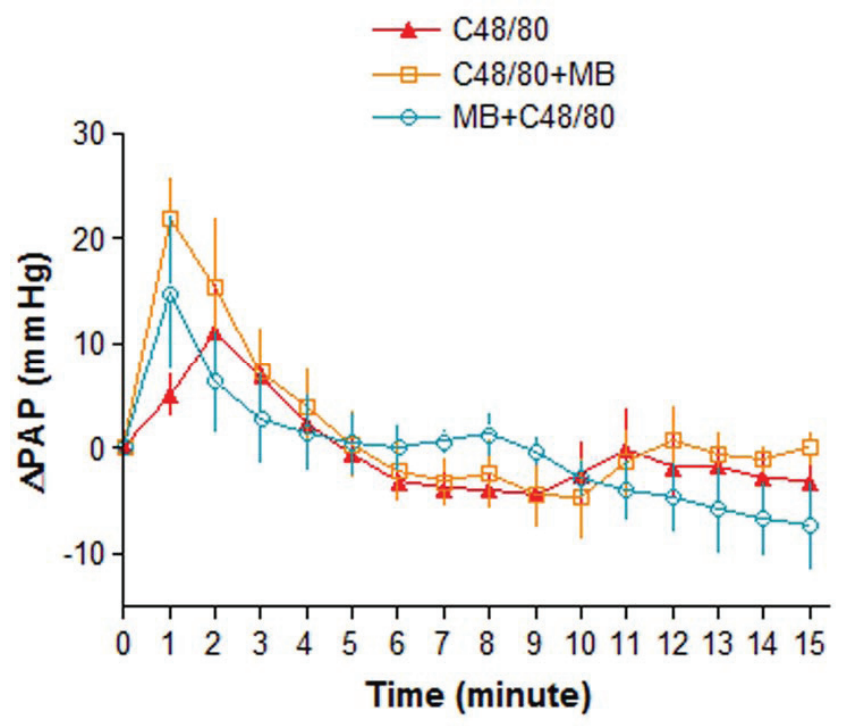

FIGURE 2B - Pulmonary arterial pressure (PAP) in the compound $48 / 80$ (C48/80), C48/80 followed by methylene blue (C48/80+MB) and methylene blue followed by $\mathrm{C} 48 / 80(\mathrm{MB}+\mathrm{C} 48 / 80)$ groups. All values are means \pm SEM ( $n=6$ in each group) and represent the PAP variation ( $\triangle \mathrm{PAP}$ $\left.=\mathrm{PAP}_{\mathrm{t}}-\mathrm{PAP}_{0}\right)$ in each time point ( $\mathrm{t}$ varies from 0 to 15 minutes).

\section{Pulmonary capillary pressure (PCP)}

Except for the $1^{\text {st }}$ minute when the $C 48 / 80$ showed an increase in the PCP compared to the control group, there were no statistical differences between the control and the MB or C48/80 (Figure 3A).

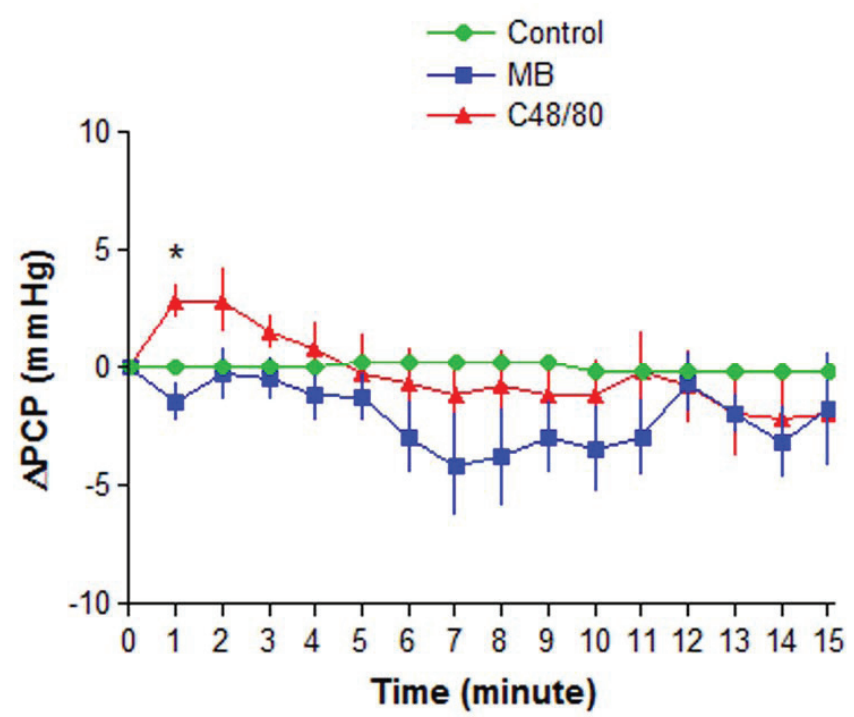

FIGURE 3A - Pulmonary capillary pressure (PCP) in the control, methylene blue (MB) and compound 48/80 (C48/80) groups. All values are means \pm SEM ( $\mathrm{n}=6$ in each group) and represent the PCP variation $\left(\triangle \mathrm{PCP}=\mathrm{PCP}_{\mathrm{t}}-\mathrm{PCP}_{\mathrm{t}=0}\right)$ in each time point ( $\mathrm{t}$ varies from 0 to 15 minutes). * $\mathrm{p}<0.05$ in the comparison between control and C48/80 (One-way ANOVA, Bonferroni's Multiple Comparison Test).
In the same way, it can be observed a statistically increase in the PCP only in the $9^{\text {th }}$ minute for the $\mathrm{MB}+\mathrm{C} 48 / 80$ in comparison to the $\mathrm{C} 48 / 80$ group, without any other difference between the $\mathrm{C} 48 / 80$ and the $\mathrm{C} 48 / 80+\mathrm{MB}$ or $\mathrm{MB}+\mathrm{C} 48 / 80$ (Figure 3B).

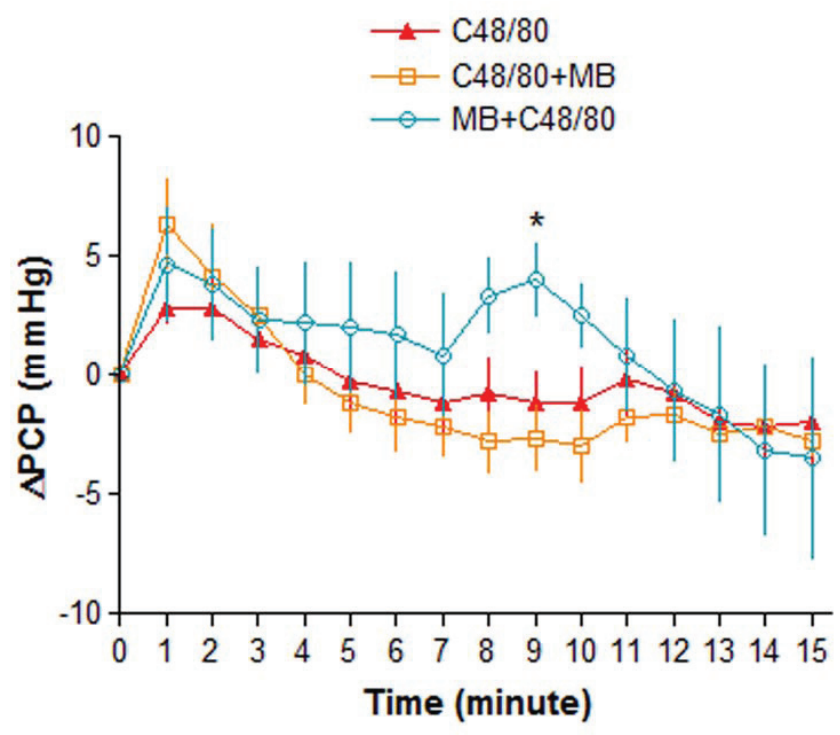

FIGURE 3B - Pulmonary capillary pressure (PCP) in the compound $48 / 80$ (C48/80), C48/80 followed by methylene blue (C48/80+MB) and methylene blue followed by $\mathrm{C} 48 / 80(\mathrm{MB}+\mathrm{C} 48 / 80)$ groups. All values are means \pm SEM ( $\mathrm{n}=6$ in each group) and represent the PCP variation $\left(\triangle \mathrm{PCP}=\mathrm{PCP}_{\mathrm{t}}-\mathrm{PCP}_{\mathrm{t}=0}\right)$ in each time point ( $\mathrm{t}$ varies from 0 to 15 minutes). $* \mathrm{p}<0.05$ in the comparison between control and C48/80 (One-way ANOVA, Bonferroni's Multiple Comparison Test).

\section{Central venous pressure (CVP)}

There were no changes in the CVP values between the control and the $\mathrm{MB}$ or $\mathrm{C} 48 / 80$ groups (Figure $4 \mathrm{~A}$ ), neither between the $\mathrm{C} 48 / 80$ and the $\mathrm{C} 48 / 80+\mathrm{MB}$ or $\mathrm{MB}+\mathrm{C} 48 / 80$ (Figure $4 \mathrm{~B}$ ).

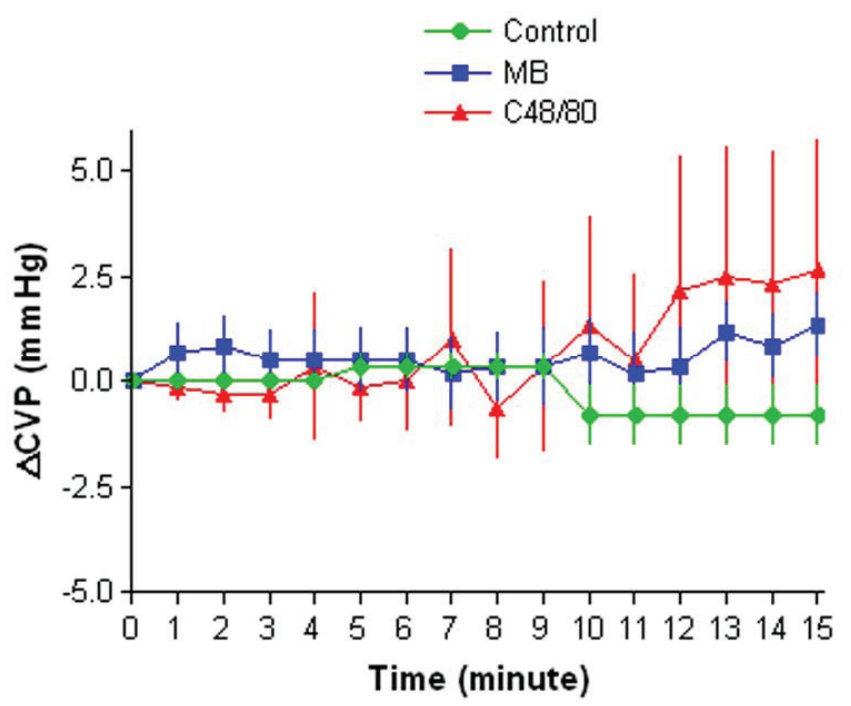

FIGURE 4A - Central venous pressure (CVP) in the control, methylene blue (MB) and compound 48/80 (C48/80) groups. All values are means \pm $\mathrm{SEM}\left(\mathrm{n}=6\right.$ in each group) and represent the CVP variation $\left(\triangle \mathrm{CVP}=\mathrm{CVP}_{\mathrm{t}}\right.$ $-\mathrm{CVP}_{\mathrm{t}=0}$ ) in each time point ( $\mathrm{t}$ varies from 0 to 15 minutes). 


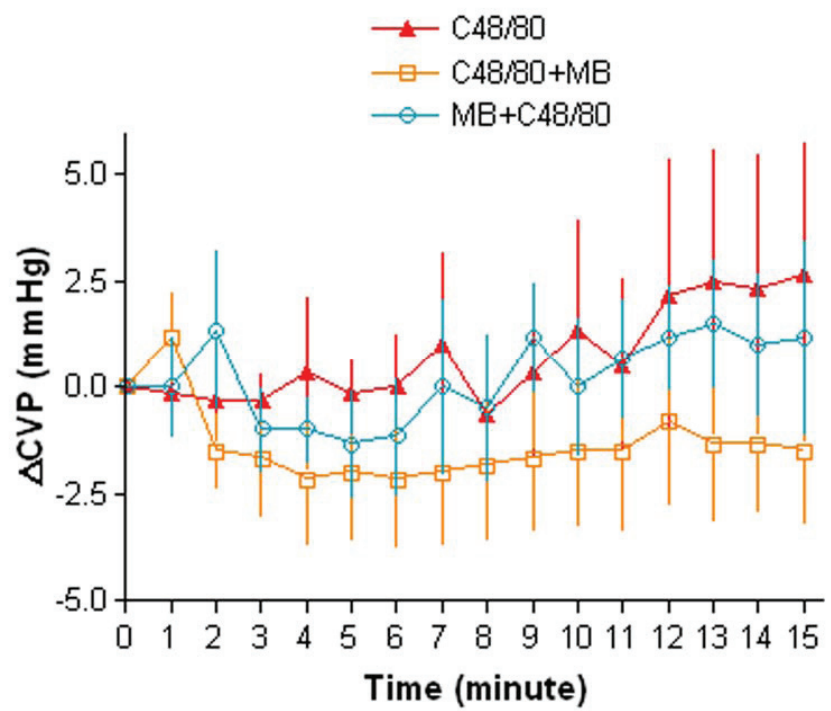

FIGURE 4B - Central venous pressure (CVP) in the compound 48/80 (C48/80), C48/80 followed by methylene blue (C48/80+MB) and methylene blue followed by $\mathrm{C} 48 / 80(\mathrm{MB}+\mathrm{C} 48 / 80)$ groups. All values are means $\pm \operatorname{SEM}$ ( $\mathrm{n}=6$ in each group) and represent the CVP variation $(\triangle \mathrm{CVP}$ $\left.=\mathrm{CVP}_{\mathrm{t}}-\mathrm{CVP}_{\mathrm{t}=0}\right)$ in each time point ( $\mathrm{t}$ varies from 0 to 15 minutes).

\section{Cardiac output (CO)}

The control group demonstrated a stable $\mathrm{CO}$ and the MB group did not differ from it. The C48/80 group presented a statistically significant decrease in the $\mathrm{CO}$ from $8^{\text {th }}$ to $15^{\text {th }}$ minute compared to the control group (Figure $5 \mathrm{~A}$ ).

The $\mathrm{CO}$ of both $\mathrm{C} 48 / 80+\mathrm{MB}$ and $\mathrm{MB}+\mathrm{C} 48 / 80$ groups were not different from the control group (Figure $5 \mathrm{~B}$ ).

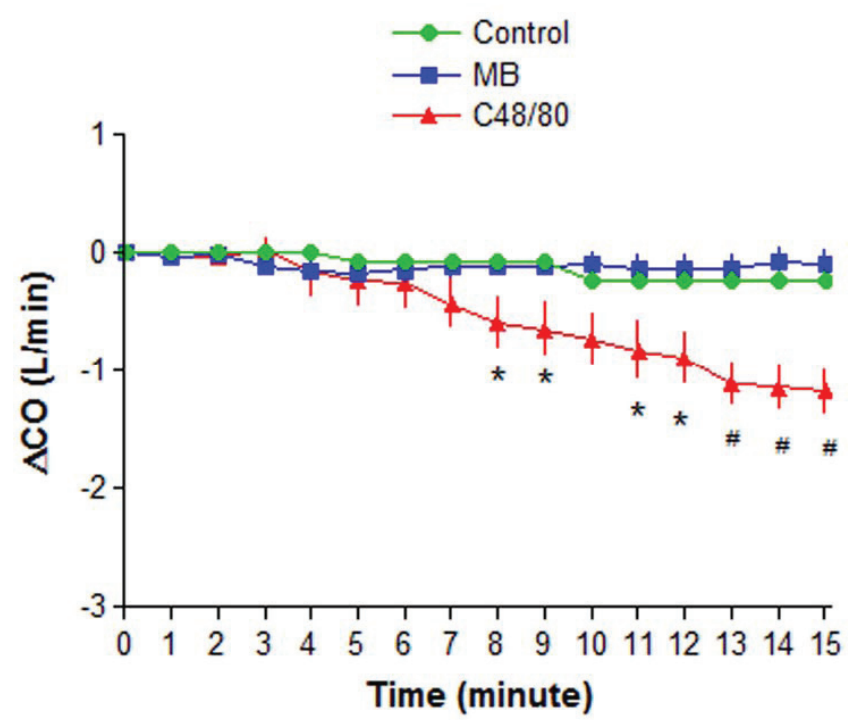

FIGURE 5A - Cardiac output (CO) in the control, methylene blue (MB) and compound $48 / 80(\mathrm{C} 48 / 80)$ groups. All values are means $\pm \operatorname{SEM}(\mathrm{n}=6$ in each group) and represent the $\mathrm{CO}$ variation $\left(\Delta \mathrm{CO}=\mathrm{CO}_{\mathrm{t}}-\mathrm{CO}_{\mathrm{t}=0}\right)$ in each time point ( $t$ varies from 0 to 15 minutes). ${ }^{*} p<0.05,{ }^{\#} p<0.001$ in the comparison between control and C48/80 (One-way ANOVA, Bonferroni's Multiple Comparison Test).

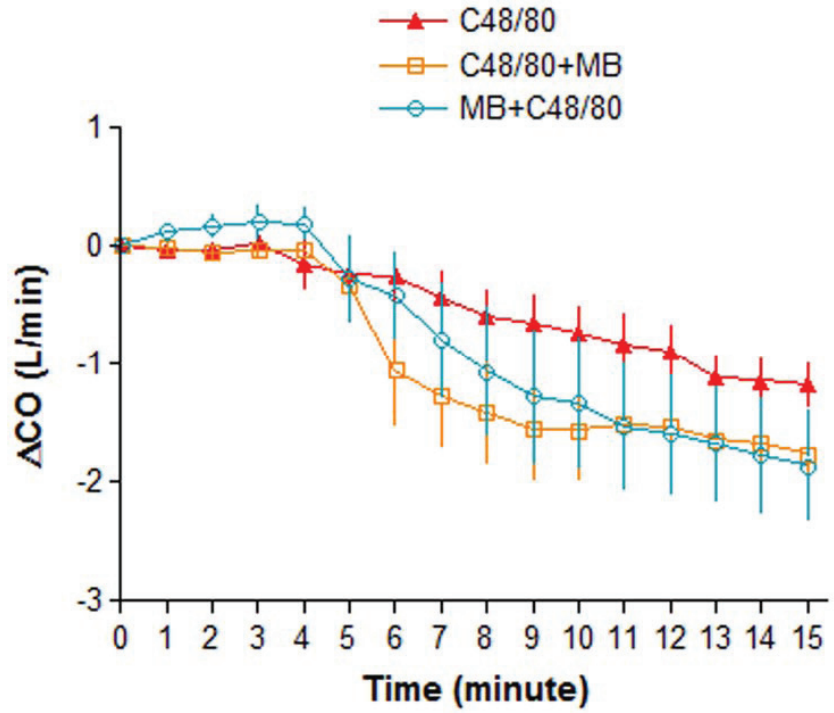

FIGURE 5B - Cardiac output (CO) in the compound 48/80 (C48/80), $\mathrm{C} 48 / 80$ followed by methylene blue $(\mathrm{C} 48 / 80+\mathrm{MB})$ and methylene blue followed by $\mathrm{C} 48 / 80(\mathrm{MB}+\mathrm{C} 48 / 80)$ groups. All values are means $\pm \mathrm{SEM}$ $\left(\mathrm{n}=6\right.$ in each group) and represent the $\mathrm{CO}$ variation $\left(\Delta \mathrm{CO}=\mathrm{CO}_{\mathrm{t}}-\mathrm{CO}_{\mathrm{t}=0}\right)$ in each time point ( $\mathrm{t}$ varies from 0 to 15 minutes).

\section{Systemic vascular resistance (SVR)}

Except for the $2^{\text {nd }}$ minute when the $\mathrm{C} 48 / 80$ demonstrated an increase in the SVR compared to the control group, there were no statistical differences between the control and the MB or C48/80 (Figure 6A).

Comparing the SVR values, there were no statistical differences between the $\mathrm{C} 48 / 80$ and the $\mathrm{C} 48 / 80+\mathrm{MB}$ or $\mathrm{MB}+\mathrm{C} 48 / 80$ (Figure 6B).

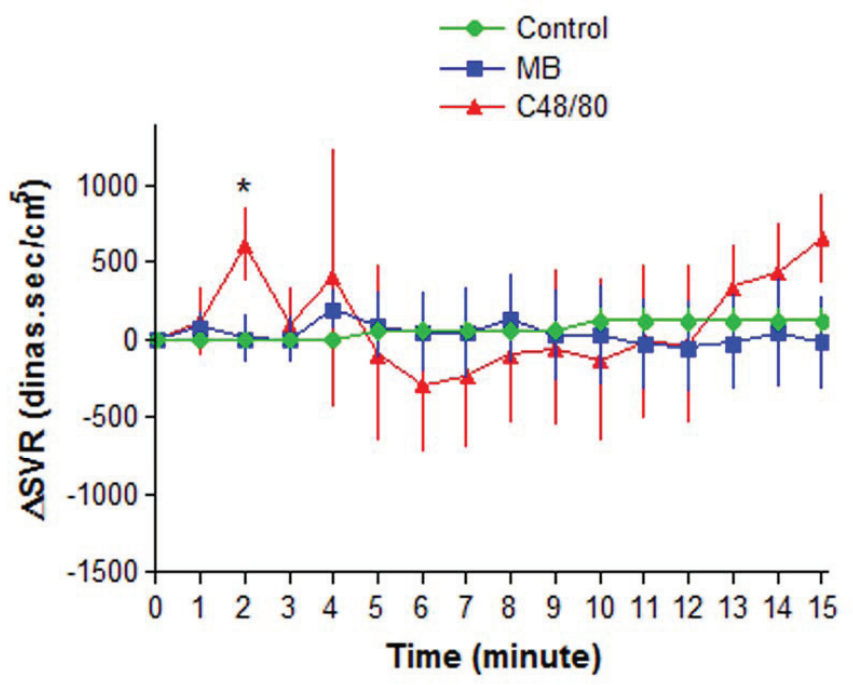

FIGURE 6A - Systemic vascular resistance (SVR) in the control, methylene blue (MB) and compound 48/80 (C48/80) groups. All values are means \pm SEM ( $n=6$ in each group) and represent the SVR variation $\left(\Delta \mathrm{SVR}=\mathrm{SVR}_{\mathrm{t}}-\mathrm{SVR}_{\mathrm{t}=0}\right)$ in each time point ( $\mathrm{t}$ varies from 0 to 15 minutes). ${ }^{*} \mathrm{p}<0.05$ in the comparison between control and C48/80 (Oneway ANOVA, Bonferroni's Multiple Comparison Test). 


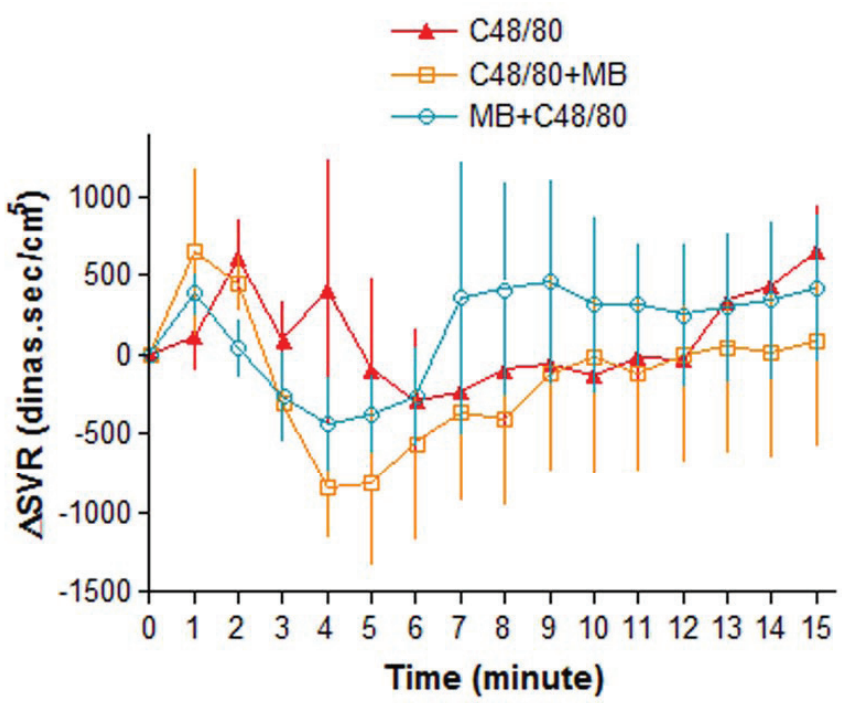

FIGURE 6B - Systemic vascular resistance (SVR) in the compound 48/80 (C48/80), C48/80 followed by methylene blue (C48/80+MB) and methylene blue followed by $\mathrm{C} 48 / 80(\mathrm{MB}+\mathrm{C} 48 / 80)$ groups. All values are means $\pm \mathrm{SEM}(\mathrm{n}=6$ in each group) and represent the $\mathrm{SVR}$ variation $(\triangle \mathrm{SVR}$ $=\mathrm{SVR}_{\mathrm{t}}-\mathrm{SVR}_{\mathrm{t}=0}$ ) in each time point ( $\mathrm{t}$ varies from 0 to 15 minutes).

\section{Pulmonary vascular resistance (PVR)}

The control group demonstrated a stable PVR. Although the other groups showed not a stable, but a variable PVR, there were no statistical differences between the control versus $\mathrm{MB}$ or $\mathrm{C} 48 / 80$ (Figure $7 \mathrm{~A}$ ) and between the $\mathrm{C} 48 / 80$ versus $\mathrm{C} 48 / 80+\mathrm{MB}$ or $\mathrm{MB}+\mathrm{C} 48 / 80$ (Figure $7 \mathrm{~B}$ ).

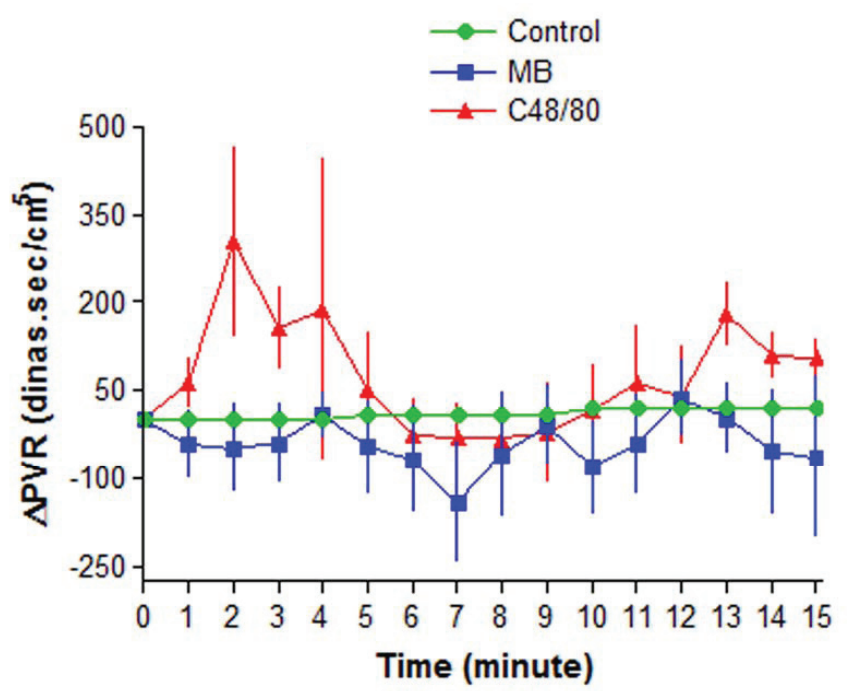

FIGURE 7A - Pulmonary vascular resistance (PVR) in the control, methylene blue (MB) and compound 48/80 (C48/80) groups. All values are means \pm SEM ( $\mathrm{n}=6$ in each group) and represent the PVR variation $\left(\triangle P V R=P_{t}-P_{t} R_{t=0}\right)$ in each time point ( $t$ varies from 0 to 15 minutes $)$.

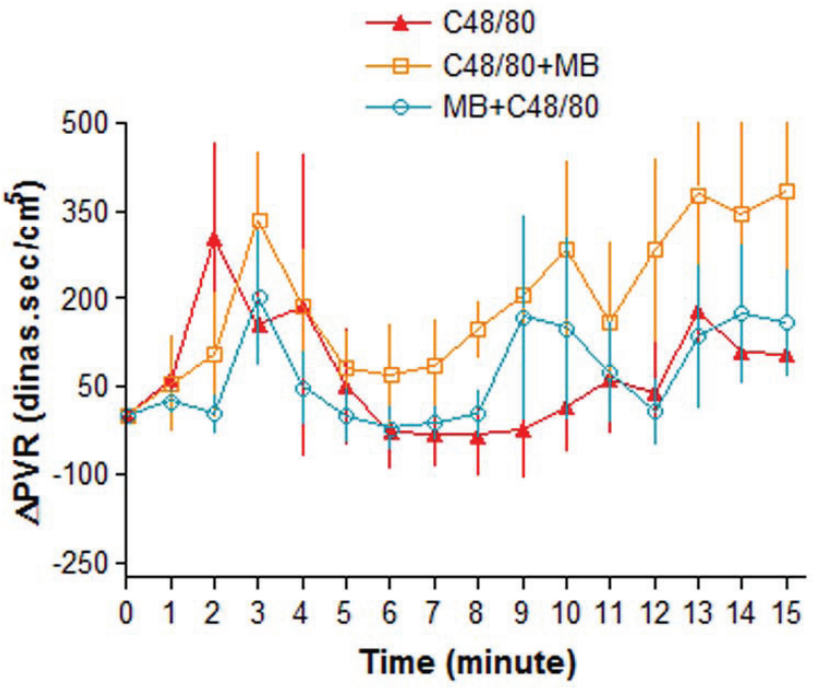

FIGURE 7B - Pulmonary vascular resistance (PVR) in the compound 48/80 (C48/80), C48/80 followed by methylene blue (C48/80+MB) and methylene blue followed by $\mathrm{C} 48 / 80(\mathrm{MB}+\mathrm{C} 48 / 80)$ groups. All values are means $\pm \operatorname{SEM}(\mathrm{n}=6$ in each group $)$ and represent the $\mathrm{PVR}$ variation $(\triangle \mathrm{PVR}$ $=\mathrm{PVR}_{\mathrm{t}}-\mathrm{PVR}_{\mathrm{t}=0}$ ) in each time point ( $\mathrm{t}$ varies from 0 to 15 minutes).

\section{Discussion}

The C48/80 has been used to produce experimental anaphylactic shock ${ }^{18,22}$. Our data showed that this compound was effective in inducing anaphylactic shock in pigs since both MAP and CO decreased after C48/80 administration. Curiously, in the first two minutes after the $\mathrm{C} 48 / 80$ injection, the animals presented a hypertensive crisis (without statistical significance) and a possible explanation for this is the direct stimulation of the hypothalamus hypophysis axis ${ }^{23}$. The $\mathrm{CO}$ reduction could be related to the negative inotropic effect of the $\mathrm{C} 48 / 80^{24}$ and could explain the CVP trend to increase. In addition, the majority of the animals exposed to $\mathrm{C} 48 / 80$ presented cutaneous hyperemia, vomits, sphincters liberation, livedo reticularis, cyanosis, ascites and intestinal ischemia and distention.

The histamine-mediated NO production has been ruled as one of the most important pathophysiological mechanisms in the cardiovascular manifestations during anaphylaxis. It was demonstrated that the $\mathrm{N} \omega$-nitro-L-arginine-methylester (L-NAME), a non-selective NOS inhibitor, reduced the mortality in $\mathrm{C} 48 / 80$ or bovine serum albumin-induced anaphylactic shock in mice ${ }^{25}$. Other studies also showed that the L-NAME diminished the hypotension and the mortality rates in mice and rats ${ }^{20,26}$. Despite these good results, the NOS inhibitors use to treat the anaphylactic shock is not completely accepted since these drugs can reduce the $\mathrm{CO}$, increasing the mortality ${ }^{13,14,19}$. It was demonstrated that although the L-NAME had attenuated the hypotension it did not 
improve cardiac depression in anaphylaxis in $\operatorname{dog} \mathrm{s}^{14}$. Furthermore, the bronchial production of NO is important to counteract the anaphylactic bronchoconstriction, and the NOS inhibition could impair this clinical condition ${ }^{13}$. Indeed, a clinical trial, evaluating the NOS inhibition to treat the septic shock, had to be discontinued due to increase in mortality ${ }^{27}$. These concepts seem to discourage the NO production inhibition and open a discussion concerning the inhibition of the NO effects on the vascular smooth muscle to treat the anaphylaxis. In this context, the $\mathrm{MB}$, recognized as a $\mathrm{GC}$ inhibitor able to abolish the NO/cGMP-dependent smooth muscle vasodilatation, emerged as a possible therapeutic strategy.

The MB has been used in various clinical conditions, for example, as an antiseptic for the urinary tract and in the methemoglobinemia and malaria treatment. It has also been demonstrated that MB can reduce the anaphylactic shock-induced hypotension in clinical and experimental studies ${ }^{18,28-32}$. A previous study of our laboratory demonstrated that the MB reduced the hypotension and increased the survival time in a model of $\mathrm{C} 48 / 80$ induced-anaphylactic shock in rabbits ${ }^{18}$. In addition, some case reports demonstrated that the MB, administered when the conventional therapy failed, reversed the hypotension in the anaphylactic shock ${ }^{28,31-33}$. Furthermore, the MB was also effective in improving the clinical signs in a different entity, the anaphylaxis with no cardiovascular collapse. However, there are a limited number of researches addressing the MB as a therapeutic option in the anaphylactic shock.

The present investigation showed that the intravenous infusion of MB alone caused no changes in the hemodynamic and clinical parameters showing that the administered MB dose was safe in this experimental model. Our results therefore corroborate other clinical data mentioning the MB therapeutic safety, which was used to revert catecholamines resistant hypotension in SIRS and anaphylaxis ${ }^{15-17,21,29,30}$.

The main goal of this study was to evaluate the MB effect on prevention and treatment of experimentally induced anaphylactic shock. Unfortunately, we showed that the MB did not prevent or reverse the $\mathrm{C} 48 / 80$-induced anaphylactic shock in this porcine model. In fact, in some time points the MAP of the animals with anaphylactic shock treated with MB decreased even more than the MAP of the animals from the C48/80 group. On the other hand, the $\mathrm{C} 48 / 80$-induced epidermal alterations disappeared after the MB infusion. However, the preventive use of MB had no or minimal effect on the cutaneous hyperemia evoked by $\mathrm{C} 48 / 80$. These results completely oppose our previous study in which rabbits and bigger MB doses were used ${ }^{18}$.

Concerning the lung circulation, although without statistical significance, our results showed a PVR trend to increase in the pigs treated with $\mathrm{MB}$ after the development of anaphylactic shock. These data deserve attention when using MB in the clinical setting, because if this increase is not due to a right ventricular dysfunction, it can be consequence of an undesirable lung hypertension, which was not observed in heart surgery patients infused with MB to treat vasoplegic syndrome ${ }^{29}$.

Despite our data, the clinical manifestations improvement brings some optimism and does not allow excluding the MB as a possible therapeutic option in the anaphylactic shock. New studies, including bigger sample size, greater MB doses, longer time observation, different experimental models, therapeutic combination with catecholamines and/or crystalloid infusions, can provide better results and even help to define safe and effective procedures for treating anaphylactic shock.

\section{Conclusion}

Despite our data, the clinical manifestations improvement brings some optimism and does not allow excluding the methylene blue as a possible therapeutic option in the anaphylactic shock.

\section{References}

1. Nava E, Palmer RM, Moncada S. Inhibition of nitric oxide synthesis in septic shock: how much is beneficial? Lancet. 1991;2128;338:1555-7.

2. Paya D, Gray GA, Stoclet JC. Effects of methylene blue on blood pressure and reactivity to norepinephrine in endotoxemic rats. J Cardiovasc Pharmacol. 1993;21:926-30.

3. Evora PRB, Seccombe JF, Pearson PJ, Schaff HV. O papel do óxido nítrico e perspectivas terapêuticas na sepse bacteriana. Rev Bras Terap Intens. 1994;6:105-7.

4. Petros A, Lamb G, Leone A, Moncada S, Bennett D, Vallance P. Effects of a nitric oxide synthase inhibitor in humans with septic shock. Cardiovasc Res. 1994;28:34-9.

5. Daemen-Gubbels CR, Groeneveld PH, Groeneveld AB, van Kamp GJ, Bronsveld W, Thijs LG. Methylene blue increases myocardial function in septic shock. Crit Care Med. 1995;23:1363-70.

6. Keaney JF Jr, Puyana JC, Francis S, Loscalzo JF, Stamler JS, Loscalzo J. Methylene blue reverses endotoxin-induced hypotension. Circ Res. 1994;74:1121-5.

7. Marczin N, Tekeres M, Salzman AL, Szabo C. Methylene blue infusion in septic shock. Crit Care Med. 1995;23:1936-8.

8. Mayer J, Hajek R, Vorlicek J, Tomiska M. Sepsis and septic shock. I. Definitions and pathophysiology. Support Care Cancer. 1995;3:10610.

9. Preiser JC, Lejeune P, Roman A, Carlier E, De Backer D, Leeman M, Kahn RJ, Vicent JL. Methylene blue administration in septic shock: a clinical trial. Crit Care Med. 1995;23:259-64.

10. Schneider F. Methylene blue infusion in septic shock. Crit Care Med. 1995;23:1935-6.

11. Zhang H, Rogiers P, Preiser JC, Spapen H, Manikis P, Metz G, Vicent JL. Effects of methylene blue on oxygen availability and regional 
blood flow during endotoxic shock. Crit Care Med. 1995;23:171121.

12. Osada S, Ichiki H, Oku H, Ishiguro K, Kunitomo M, Semma M. Participation of nitric oxide in mouse anaphylactic hypotension. Eur J Pharmacol. 1994;252:347-50.

13. Mitsuhata H, Shimizu R, Yokoyama MM. Role of nitric oxide in anaphylactic shock. J Clin Immunol. 1995;15:277-83.

14. Mitsuhata H, Takeuchi H, Saitoh J, Hasome N, Horiguchi Y, Shimizu $\mathrm{R}$. An inhibitor of nitric oxide synthase, $\mathrm{N}$ omega-nitro-L-argininemethyl ester, attenuates hypotension but does not improve cardiac depression in anaphylaxis in dogs. Shock. 1995;3:447-54.

15. Evora PR, Ribeiro PJ, de Andrade JC. Methylene blue administration in SIRS after cardiac operations. Ann Thorac Surg. 1997;63:1212-3.

16. Evora PR, Roselino CH, Schiaveto PM. Methylene blue in anaphylactic shock. Ann Emerg Med. 1997;30:240.

17. Evora PRB, Roselino CH, Schiavetto PM. Utilização do azul de metileno no tratamento do choque anafilático. Uma proposição clínica e apresentação de três casos. Rev Bras Terap Intens. 1997;9:126-31.

18. Buzato MA, Viaro F, Piccinato CE, Evora PR. The use of methylene blue in the treatment of anaphylactic shock induced by compound 48/80: experimental studies in rabbits. Shock. 2005;23:582-7.

19. Bellou A, Lambert H, Gillois P, Montemont C, Gerard P, Vauthier E, Sainte-Laudy J, Longrois D, Guéant JL, Mallié JP. Constitutive nitric oxide synthase inhibition combined with histamine and serotonin receptor blockade improves the initial ovalbumin-induced arterial hypotension but decreases the survival time in brown norway rats anaphylactic shock. Shock. 2003;19:71-8.

20. Cauwels A, Janssen B, Buys E, Sips P, Brouckaert P. Anaphylactic shock depends on PI3K and eNOS-derived NO. J Clin Invest. 2006;116:2244-51.

21. Evora PR, Oliveira Neto AM, Duarte NM, Vicente WV. Methylene blue as treatment for contrast medium-induced anaphylaxis. J Postgrad Med. 2002;48:327.

22. Zwadlo-Klarwasser G, Braam U, Muhl-Zurbes P, Schmutzler W. Macrophages and lymphocytes: alternative sources of histamine. Agents Actions. 1994;41:C99-100.

23. Foldes A, Nemethy Z, Szalay O, Kovacs KJ. Anaphylactoid reactions activate hypothalamo-pituitary-adrenocortical axis: comparison with endotoxic reactions. Brain Res Bull. 2000;52:573-9.

24. Gomes JC, Antonio A. Effects of compound $48 / 80$ on the guinea-pig isolated heart: a comparison with the in vitro cardiac anaphylaxis. Pharmacol Res Commun. 1981;13:873-90.

25. Amir S, English AM. An inhibitor of nitric oxide production, NGnitro-L-arginine-methyl ester, improves survival in anaphylactic shock. Eur J Pharmacol. 1991;203:125-7.

26. Takano H, Liu W, Zhao Z, Cui S, Zhang W, Shibamoto T. N(G)nitro-L-arginine methyl ester, but not methylene blue, attenuates anaphylactic hypotension in anesthetized mice. J Pharmacol Sci. 2007; 104:212-7.

27. Alexander JH, Reynolds HR, Stebbins AL, Dzavik V, Harrington RA, Van de Werf F, Hockman JS. Effect of tilarginine acetate in patients with acute myocardial infarction and cardiogenic shock: the TRIUMPH randomized controlled trial. JAMA. 2000;297:1657-66.
28. Del Duca D, Sheth SS, Clarke AE, Lachapelle KJ, Ergina PL. Use of methylene blue for catecholamine-refractory vasoplegia from protamine and aprotinin. Ann Thorac Surg. 2009;87:640-2.

29. Andrade JCS, Batista Filho ML, Evora PRB, Tavares JR, Buffolo E, Ribeiro EE, Silva LA Teles CA, Petrizzo A, Barata Filho VV, Duprat R. Utilização do azul de metileno no tratamento da síndrome vasoplégica após cirurgia cardíaca. Rev Bras Cir Cardiovasc. 1996;11:107-14.

30. Evora PR. Should methylene blue be the drug of choice to treat vasoplegias caused by cardiopulmonary bypass and anaphylactic shock? J Thorac Cardiovasc Surg. 2000;119:632-4.

31. Rodrigues JM, Pazin Filho A, Rodrigues AJ, Vicente WV, Evora PR. Methylene blue for clinical anaphylaxis treatment: a case report. Sao Paulo Med J. 2007;125:60-2.

32. Stocche RM, Garcia LV, Reis MP, Klamt JG, Evora PR. Methylene blue to treat anaphylaxis during anesthesia: case report. Rev Bras Anestesiol. 2004;54:809-14.

33. Oliveira Neto AM, Duarte NM, Vicente WV, Viaro F, Evora PR. Methylene blue: an effective treatment for contrast medium-induced anaphylaxis. Med Sci Monit. 2003;9:CS102-6.

\section{Correspondence:}

Paulo Roberto Barbosa Evora

Rua Rui Barbosa, 367/15

14015-120 Ribeirão Preto - São Paulo Brasil

prbevora@netsite.com.br

Received: April 26, 2011

Review: June 21, 2011

Accepted: July 27, 2011

Conflict of interest: none

Financial source: Fundação de Apoio ao Ensino, Pesquisa e Assistência do Hospital das Clínicas da Faculdade de Medicina de Ribeirão Preto da Universidade de São Paulo (FAEPA-HC/FMRPUSP) and Fundação de Amparo à Pesquisa do Estado de São Paulo (FAPESP).

${ }^{1}$ Research performed at Laboratory of Endothelial Function, Department of Surgery and Anatomy, Ribeirao Preto Medical School, Sao Paulo University ((FMRP-USP), Brazil.

Presented at the XII National Congress on Experimental Surgery of the Brazilian Society for the Development of Research in Surgery-SOBRADPEC 2011 October 26-29, Ribeirao Preto-SP, Brazil 